protocols will require ratification by three countries to enter into force. It is difficult to predict how long this may take.*

It goes without saying that the treaty and its protocols are binding only for those countries which ratify them. This is why the Alps can be protected from environmental degradation and unsustainable, unaesthetic development only when all seven Alpine countries have ratified the international accords.

Facts and statistics about the Alps - an area that stretches from the French Alps along the Mediterranean Sea for 1,200 kilometres through the prosperous heart of Europe - are apt to be straggering. To begin with, around 90 million tons of merchandise are transported annually over the Alps - mostly in trucks - and by AD 2010 this commercial traffic is predicted to grow by up to $100 \%$.

'Alpine experts strongly favour shifting a high proportion of lorry transport of goods to rail transportation', says Josef Biedermann, the Liechtensteiner President of the International Commission for the Protection of the Alps (CIPRA), 'and the Alpine Convention already makes this point.' CIPRA may legitimately claim credit for a decadeslong effort to persuade Alpine governments that they need such a treaty and a united policy for the preservation and sensible development of Europe's largest terrestrial superecocomplex.

\section{Importance of Tourism}

Alpine tourism (for skiing, mountain climbing, hiking, or just relaxing in the mountain air) is a $\$ 52$ thousand million business - estimated to represent one-fourth of the annual turnover of global tourism. It is hardly surprising to learn that more than $50 \%$ of the 11 million people who live in the Alps depend directly or indirectly on tourism.

Excluding day-trippers, who are virtually impossible to count, or people just passing through the Alps, very approximately 100 million tourists spend vacations in the Alps annually. Of these, some $75 \%$ arrive by car, $60 \%$ are overnight or weekend visitors, and $40 \%$ are longer-term holidaymakers.

Every year between 150 and 200 million people drive north or south across Alpine passes. This already substantial traffic is expected to increase by 50 to $70 \%$ by the year 2010 - only about 15 years off. "For the first time, the Alpine Convention links the economy, culture, and the environment', says Dr Flemming. 'This calls for a common awareness of the Alps by all people living in this unique region. Overcoming regional, national, linguistic, and cultural, barriers throughout the Alpine arc is of vital importance for the Alpine population.'

The Alps are practically synonymous with skiing. How many kilometres of ski slopes are there in the seven Alpine countries? The answer depends on who you ask: lift operators say $18,000 \mathrm{~km}$, but Nature protection groups estimate it as 40,000 .

In 1990 CIPRA counted about 100 golf courses in the
Alps, but in 1992 there were already around 150, and by the end of 1998 the number will probably double to around 300. In spite of the ecological abuses that arise from such activities, the huge number of tourists enjoying the Alps represent an enormous potential of defenders and protectors of the region. 'Up to now, the Alps have not been able to exploit this potential', says Jacques MorierGenoud, former head of the Swiss League for the Protection of Nature.

\section{Many Controls Needed}

In considering how to cope with rapidly-rising numbers of tourists, the increase in commercial transport, and other problems, as well as with the different levels of development of various Alpine regions, the drafters of the treaty and protocols have come up with two overall strategies:

On one hand, they intend to set limits to certain abuses of Nature in order to avoid further damage to the environment and the landscape, and to reduce pollution. Thus they have taken a strong stand against heliskiing, motor sleighs, moto-cross machines, engine-driven cross-country vehicles, and ultra-light planes, and they advocate controls over construction of new roads and tourist infrastructure.

On the other hand these Alpine experts offer guidelines for sensible development, particularly for those regions that are not yet suffering from overdevelopment. But they need a strategy to secure their economic and cultural future, e.g. better public transport facilities, a focus on 'green' and quality tourism, incentives for long-term vacations instead of day visits, the regeneration of water systems, and encouragement of energy-saving technologies.

\section{Revive Alpine Way of Life}

The Alps are not 'the playground of Europe', but a civilization and a way of life that has been fashioned over many centuries. The successful implementation of the treaty requires the cooperation of 11 million people living in 5,800 hamlets and villages, towns, and cities, in 43 regions, in taking care of their living environment.

Until recently when developers arrived, mountain farmers were the landscape architects of the Alps. If farming, forestry, and the social tissue of mountain communities, are all to be revitalized, incentives have to be offered to mountain farmers - not just government subsidies, however justified they may be, but practical assistance in developing diversified, original, and economically viable, farming schemes. Through this assistance, the treaty may encourage Alpine farmers to meet the rising demand for all-natural products, such as high-quality cheeses and other dairy products, honey, fruit, and herbs.

ANDREA DALLINGER
Alpenforschungsinstitut CIPRA
Adelgundenstrasse 18
80538 Munich
Germany.

\title{
Short Courses on Life-zone Ecology and Tropical Dendrology Offered in English and Spanish
}

$T_{0}$ The classification of the Earth's ecosystems and ecocomplexes affects almost all ecological and geographical science. Additionally, the identification of plants is closely related to the classification of ecosystems which on land are largely characterized by their plant components. From an academic perspective both subjects are crucial, as

\footnotetext{
* On the returned corrected proof the Author wrote 'Please note that Austria is presently not willing to sign the 2 protocols 'tourism' and 'transport', as they consider it not restrictive enough! - Ed.
}

they form the basis for sustainable resource management and biodiversity preservation.

L.R. Holdridge's Life-zone Ecology classification system and Tropical Dendrology (a system to identify forest trees) have been used by scientists and other professionals in the tropics for more than 30 years. Furthermore, based on the Life-zone Ecology system, several sound practical applications have been developed by the Tropical Science Center to be used in rural development, sustainable resource management, watershed management, land-use 
ference offers an exciting opportunity for field workers, community organizers, involved officials, and researchers, to exchange and sharpen views while sharing their varied experiences.

The Conference proceedings will be published as part of the Yale School of Forestry Bulletin series. Further information on participation and Conference contents may be obtained from the undersigned:

ANDI EICHER, Organizing Secretary
ISTF Conference Committee
Yale School of Forestry and Environmental Studies
Sage Hall
205 Prospect Street
New Haven
Connecticut 06511, USA.

Tel. (203) 562-7851

Fax (203) 562-5942.

\section{Important Prospect}

UNESCO'S INTERNATIONAL CONFERENCE ON BIOSPHERE RESERVES, TO BE HELd IN SEVILla, SPAIN, DURING 20-25 MARCH 1995

As a follow-up of a congress convened by UNESCO and UNEP in Minsk (Belarus) in 1983, an 'Action Plan for Biosphere Reserves' for the period 1985-94 was formally adopted by these two organizations and supported by FAO and IUCN. During that period, the concept of Biosphere Reserves was refined in the light of field experience and practical requirements. Biosphere Reserves constitute a non-conventional type of protected area in which the conservation of ecosystems and of their biological diversity is combined with sustainable use of natural resources for the benefit of local people and with relevant scientific research and information exchange. No fewer than 324 Biosphere Reserves, located in 82 countries and covering over 210 million hectares, have so far been designated and constitute already an informal cooperative network under the Man and the Biosphere (MAB) Programme of UNESCO.

The time has now come for a thorough evaluation of progress made under the existing Action Plan, and for defining the measures to be taken for future action at the level of existing Biosphere Reserves, of individual countries, and of the international or regional organizations concerned. For this reason, the General Conference of UNESCO at its 27th Session in November 1993, upon a proposal made by the Spanish authorities, has invited the Director-General to convene an International Conference of experts on Biosphere Reserves which will take place in Sevilla from 20 to 25 March 1995.
On the basis of the examination and evaluation of past and current activities and of experience acquired, the Conference is expected to prepare a new Action Plan for the years to come and to explore the role of Biosphere Reserves in environment-development issues at the regional or landscape level at the beginning of the $21 \mathrm{st}$ century. The Conference will also discuss a much-needed statutory framework for the International Network of Biosphere Reserves, with a view to enhancing the functioning and visibility of the present network. These documents will be submitted subsequently for endorsement or adoption by the General Conference of UNESCO in the Autumn of 1995. The work of the Conference will be conducted in plenary sessions as well as in three commissions in which a number of case-studies, dealing respectively with People and Biosphere Reserves, Biosphere Reserve Management, and Biosphere Reserves for Science and Conservation, will be presented. In addition, participants are invited to present posters and exhibits on their achievements in specific Biosphere Reserves.

The Conference will have English, French, and Spanish, simultaneous interpretation, and will take place at the International Congress Centre in Sevilla, Spain. General information concerning the Conference and all matters relating to its programme should be addressed to:

\section{Pierre Lasserre, Director}

Division of Ecological Sciences (Sevilla Conference)

UNESCO

1 Rue Miollis

75732 Paris Cedex 15

France.

Fax (33) 1.40.65.98.97

Recent events in a number of major countries, including Argentina, Australia, Canada, China, France, Germany, Mexico, Spain, the United Kingdom, and the USA, have demonstrated the growing interest in a full implementation of the Biosphere Reserve concept as a valuable tool in reconciling environment and development concerns. The need to improve the quality and operations of the International Network has also been strongly expressed. At a time when the Convention on Biological Diversity is entering into force, and when the relevant parts of Agenda 21 are being considered by the UN Commission on Sustainable Development, the importance of the Sevilla Conference should be fully appreciated.

MICHEL BATISSE, Senior Environmental Adviser
UNESCO
7 Place de Fontenoy
75352 PARIS O7 SP
France.

\section{(Continued from page 280)}

capability, assessment of environmental impact, territorial zoning, and ecosystem characterization in protected areas.

Recently, the US National Atmospheric and Space Agency (NASA) prepared an earth map of life-zone ecosystems which has been used to monitor and predict vegetation changes due to increase of atmospheric $\mathrm{CO}_{2}$ (the so-called 'greenhouse effect'). Also, in 1992, the World Conservation Monitoring Centre (WCMC) gave strong support to the Holdridge Life-zone system by including it in their official publication Global Biodiversity; Status of Earth Living Resources. WCMC is jointly directed by IUCN, UNEP, and WWF.

Through participation in the Life-zone Ecology course, students should have gained sufficient knowledge to implement sound, practical applications of the system in such activities as those mentioned in the preceding paragraphs. After attending the Tropical Dendrology course, students should be accomplished in identifying a large proportion of 
In section III, entitled 'Made in America', it is stressed that 'soft ecology' is a dominant film-theme; because of Americans being increasingly conscious about their environment, television grabbed this theme and endeavours to keep its public aware of what can be done to save the planet. While 'Hollywood' keeps on harping on the supremacy of the 'American way of life', it might do better to sell the idea of interdependency associated with the environment. A fascinating review of current, and not so current, American-produced films on the environment is provided. The range is wide, the topics varied, and it includes such well-known releases as e.g. 'Great Lakes, Bitter Legacy', 'The Spirit of Crazy Horse', and 'Yellowstone under Fire'. Books and records are also scrutinized.

Whether such a periodical, in a world saturated by journals, can survive, time only will prove; but we think it deserves to.

\section{Marie-Claire Chaineux Catholic University of Mons (FUCAM) Chemin du Quesnoy 31 B-7803 Bouvignies Belgium.}

NOTICE: Recycling and the Politics of Urban Waste, by MATTHEW Gandy. Available from Spring 1994 from all good bookshops for $£ 12.95$ (paperback) or direct from the publisher (please add 10\% p\&p): Earthscan, 120 Pentonville Road, London N1 9JN, England, UK: Tel. (071) 2780433; Fax (071) 278-1142.

The affluence of western society has given rise to unprecedented quantities of waste, presenting one of the most intractable environmental problems for contemporary society. Waste management is one of the most pressing concerns that city authorities world-wide have to deal with, and all the available avenues of alleviation must be explored.

This book examines recycling and municipal waste management in three major cities: London, New York, and Hamburg. In Recycling and the Politics of Urban Waste, Matthew Gandy analyses a range of political and economic issues to illustrate how any reduction in the size of the waste-stream, in order to achieve more equitable and environmentally sustainable patterns of resource use, is incompatible with the current emphasis on the use of the market for environmental protection. Case-studies show how, contrary to the hopes of many environmentalists and policymakers, municipal waste management is moving steadily towards the profitable option of incineration with energy recovery, rather than the recycling of materials or waste reduction at source. The evidence suggests that the achievement of a more sustainable pattern of recycling and waste management policy would demand a fundamental change in public policy, to give government a more active role in environmental protection. Matthew Gandy is a lecturer in geography at the University of Sussex in southern England.

\section{(Concluded from page 285)}

tropical trees and shrubs - to family, genus, and in some cases species. Course participants will also gain special skills enabling them to continue making progress on their own upon returning to their respective countries.

Courses last 3 working weeks each. In 1995 they will be offered from 6 to 24 February (Dendrology, in English); from 13 to 31 March (Dendrology, in Spanish); from April 17 to May 5 (Ecology in Spanish); and from June 19 to July 7 (Ecology in English). Costs are US \$2,500 for Tropical Dendrology either in Spanish or in English, and US \$2,700
NoticE: Renewable Energy: Sources for Fuels and

Electricity, Edited by ThOMAS B. JOHANSSON, HENRY Kelly, Amulya K.N. Reddy \& Robert H. Williams.

A state-of-the-art assessment of the technical and economic prospects for making fuels and electricity from renewable sources of energy. Fifty of the world's leading experts contribute 23 chapters to provide a sound and authoritative look at new ways to satisfy the growing world demand for energy, covering all forms of renewable energy.

The first comprehensive work on alternative energy to appear for more than a decade, it is currently the definitive reference on the subject. According to the President of the Rockefeller Foundation, it 'will introduce you to an absolutely critical transition [which] the planet will [need to] make over the next two decades - the change to renewable, clean sources of energy".

Thomas B. Johansson is Professor of Energy Systems Analysis at the University of Lund, Sweden; Henry Kelly is senior associate at the Office of Technology Assessment of the US Congress; Amulya K.N. Reddy is President of the International Energy Initiative, Bangalore, India; and Robert H. Williams is senior research scientist at the Center for Energy and Environmental Studies, Princeton University, New Jersey, USA.

Available from Earthscan Publications Ltd, 120 Pentonville Road, London N1 9JN, England, UK: tel. (071) 278 0433: fax: (071) 278 1142: v + 1200 pp., illustr., 22.6 $\times 15 \times 5.3 \mathrm{~cm}$., hardback $£ 60$, paperback $£ 30,1993$.

\section{NoticE: Environmental Remote Sensing From Regional} to Global Scales, Edited by GILES FOODY \& PAUL CURRAN.

Remote sensing by satellites provides scientists with a ready means of analysing the terrestrial environment in fields as diverse as meteorology, agriculture, town planning, and ecology. Allied to the powerful computer-based methodologies of geographic information systems, image processing, and cartographic techniques, perhaps its most important aspect is the way which it can allow synoptic interpretation of complex geographical phenomena from global to local scales.

Environmental Remote Sensing From Regional to Global Scales provides a benchmark collection of papers to demonstrate the flexibility and power of ERS techniques in a variety of contexts and scales. To achieve this end, a group of leading specialists have contributed surveys to the field. However, for effective appplication no high level of technical expertise is required, with the result that this book is accessible and helpful to any research scientist, student, or professional, who wishes to assess the application of these techniques to his/her own field of study.

Published Spring 1994 by John Wiley \& Sons Ltd, Baffins Lane, Chichester, West Sussex PO19 1UD, England, UK, '256 pages' at $£ 55 / \$ 88$.

(Concluded on page 273)

for Life-zone Ecology (please note that these amounts do not include air fares). For additional information, contact the undersigned:

HuMBERTO JiMÉNEZ SAA
Tropical Science Center
PO Box $8-3870$
San José 1000
Costa Rica.
Tel. (506) 252649 \& 533267
Fax (506) 534963

Tropical Science Center

PO Box 8-3870

Costa Rica.

Fax (506) 534963 